sion lest a judgement in favor of the federal act render the employer subject to criminal penalties for violating that act, merely because the record did not show that he had insured as required. The record could not be expected to show a fact so irrelevant under the Court's previous criterion. As a matter of fact, in respondent's petition for rehearing, ${ }^{28}$ proof was promptly offered that he had so insured.

For these reasons, it is likely that only one important presumption was established in the Davis case, namely, one favoring the employee's own choice of statutes. Henceforth, then, instead of distinguishing merely between "local" and "nonlocal" work, the Court must at times distinguish between cases which present new-type situations and those which constitute only variations on preceding cases. This will occur as often as an employee attempts to recover under a statute other than the one to which he would be subjected without the presumption established in the Davis case. ${ }^{29}$ For example, if an employee claiming under a state act is engaged in work which the Court decides is local, it is unnecessary for the Court to explain whether it reached its decision on precedent or on the particular facts of the case. If, however, that same employee claims under the federal act, the decision will turn on whether or not the case is within the "twilight zone," recovery being denied if it is not, and given if it is.

The Court has not lightened its own burden; it has merely set up a new criterion. Employees, on the other hand, will experience a positive diminution of uncertainty. As for employers, it may be contended that this decision forces them to insure under two statutes instead of one wherever the work is of uncertain character. Actually, however, employers with such work took a substantial risk, even prior to the Davis case, if they did not insure under both statutes. Their risk then has only been increased, not created, by this case.

\title{
THE APPLICATION OF THE RULE IN SHELLEY'S CASE
}

In the case from which it takes its name, the rule in Shelley's Case is stated by Lord Coke to apply, "When the ancestor by any gift or conveyance takes an estate of freehold, and in the same gift or conveyance an estate is limited either mediately or immediately to his heirs in fee or in tail; that always in such cases 'the heirs' are words of limitation of the estate, and not words of purchase."'

${ }^{28}$ Respondent's petition for rehearing, p. 6.

29 Regardless of which statute he thinks would govern under the old "local-nonlocal" rule, an employee will tend to sue under whichever statute offers greater compensation so long as he thinks his case differs sufficiently from any prior case to take him out of that rule and give him instead the benefits of the Davis presumption.

${ }^{x}$ I Co. Rep. 93b, I04a ( $158 \mathrm{r}$ ). For an authoritative discussion of Shelley's Case itself, see Challis, Real Property, I 54-62 (3d ed. IgII). A modern and more limited expression of the rule can be found in the Rest., Property $\S 312$ (1940). In England, the rule has been abrogated by statute, Law of Property Act (I925) I5 Geo. V, c. 20, § I3I. Some 34 American jurisdictions have also wholly or partially abrogated the rule by statute. Rest., Property $\S 3$ I3 (I940). 
Complete agreement has never been reached among the authorities as to the historical explanation of the rule. ${ }^{2}$ Whatever its origin, with the decline of feudalism the only justification for the retention of the rule was that, to a certain degree, it facilitated the alienability of property, ${ }^{3}$ a consideration far overshadowed by the undesirability of a rule which so frequently defeats the manifest intent of grantors and testators. Nevertheless, the deep-rooted and in many ways understandable conservatism of the English conveyancers with regard to rules of law prevailed, and the rule in Shelley's Case remained as enunciated by Lord Coke, a rule of property. ${ }^{4}$ This occurred, however, only after a struggle of three centuries, during which the English courts were unable to reach a definite conclusion as to how far they might deviate from the rule in order to carry out the intent of the testator or grantor. ${ }^{5}$

That the word "heirs" appearing in an instrument under the circumstances described by Lord Coke, would always be regarded as a word of limitation, irrespective of the intent of the creator of the instrument, has generally been regarded as settled by the case of Coulson $v$. Coulson. ${ }^{6}$ In that case there was a devise to $\mathrm{A}$ for life, a remainder to trustees to preserve the contingent remainders during the life of $A$, with a remainder to the heirs of A's body. The trust device permits only one conclusion, and that an obvious and unambiguous one on the part of the testator, namely, that $\mathrm{A}$ is to take only a life estate. Nevertheless, the court held that the rule applied so that the remainder to the heirs of A's body should be read as a vested remainder in tail to A. Although the intermediate estate was regarded as preventing a merger, the effect of the rule was to place two estates in the ancestor. 7 Notwithstanding the importance and the uniqueness of the problem presented by the case, the decision was handed down without discussion. ${ }^{8}$

3 A collection of some of the various views as to the origin of the rule is contained in I Simes, Law of Future Interests $\S \S$ Ir 5-r6 (I936).

${ }_{3}^{3}$ See Baker v. Scott, 62 Ill, 86, 96 (I87r).

4 Simes, op. cit. supra note $2, \S$ II5. Since the presence of the proper technical language must first be determined by the ordinary rules of construction before the rule can apply, some writers are inclined to consider the rule as a mixed rule of property and construction. Leach, Cases and Materials on the Law of Future Interests 1 20-22 (2d ed. r940).

5 For a short discussion of the tortuous evolution of the rule during this period, see Van Grutten v. Foxwell, [I897] A. C. $658,667-81 ; 3$ Holdsworth, History of English Law ro7-rir (I923).

62 Atk. 247 (I74I). As a word of limitation, "heirs" presupposes an indefinite succession of generations. Whether the word "heirs" could be used to designate a particular class of purchasers to take upon the death of the ancestor is not regarded as fully settled under the English law. Simes, op. cit. supra note $2, \S$ II5.

7 Cf. Carpenter v. Hubbard, 263 Mll. 57 r, 105 N.E. 688 (rgra); but see Bucklin v. Creighton, I8 R.I. 325, 27 Atl. 221 (1893).

${ }^{8} \mathrm{At}$ the time the Coulson case was pending before the King's Bench, the disposition of a somewhat similar cause was postponed awaiting the Coulson decision. Bagshaw v. Spencer, 2 Atk. 246 (I74I). Subsequently, an attempt was made to distinguish the Coulson case on the 
Although occasionally criticized in later decisions, the Coulson case was accepted as settled law. In the subsequent case of Perrin v. Blake, 9 Lord Mansfield made one final attempt to subordinate the rule in Shelley's case to the intention of the testator or grantor. This decision, which threatened to upset an established rule of property, was severely criticized by the English conveyancers. ${ }^{10}$ On appeal, the Exchequer Chamber reversed this decision, which threatened to reduce the rule to a rule of construction, and restored it as a settled rule of property. ${ }^{x I}$

Notwithstanding the decision in the Coulson case and the reafirmation of that position in Perrin v. Biake, there remained a possible situation in which the application of the rule might be regarded as unsettled. Lord Coke had stated that the rule in Shelley's Case applied, "When the ancestor by any gift or conveyance takes an estate of freehold ...." (italics added). Assume that for some reason the limitation to the ancestor fails so that he does not take an estate of freehold at the time the instrument becomes operative. ${ }^{22}$ In this situation, would the limitation to his heirs still fall within the rule in Shelley's Case, or, the initial step in the operation of the rule having failed, would the courts follow the indicated intent of the donor, thus giving a separate estate to the heirs? ${ }^{\mathrm{x}_{3}}$ Justice Blackstone suggested in Perrin v. Blake ${ }^{\mathrm{T} 4}$ that the remainder to the heirs was not to be treated in every instance as a phrase of limitation describing the size of the ancestor's estate. He cited one instance in which the heirs may take

basis that the rule in Shelley's Case was inapplicable to equitable limitations. Bagshaw v. Spencer, I Ves. Sr. 142 ( 1748 ). However, the doctrine of the Bagshaw case was overruled in Wright v. Pearson, I Eden rrg (I758). Where there is an executory trust, equity does not follow the law, since conformance with the strict provisions of the settlement requires that the party designated as a life tenant should receive only a life estate. See 3 Jarman, Wills $1827-40$ (7th ed. I930). Since there is no property notion prevailing in the United States that corresponds to the English rule of strict settlements, this English exception is relatively unimportant to the application of the rule in this country. Carey and Schuyler, Future Interests in Illinois $\$ 99$ (I94I).

$9 \mathrm{I} \mathrm{Bl}$. W. 672 ( $\mathrm{I} 76 \mathrm{~g})$. The opinions delivered in the King's Bench are collected in I Hargrave, Collectanea Juridica 283-322 (I79r).

${ }^{10}$ No decision of modern times has been subjected to the attack and publicity that this case aroused. A short history of the conflict is restated in Van Grutten v. Foxwell, [r897] A. C. $65^{8}, 670-71$; see also Leach, op. cit. supra note 4 , at $132-36$; Fearne, Contingent Remainders I48-73 (6th ed. 1809 ).

II Perrin v. Blake, I Bl. W. 672 (r769).

12 The estate of freehold, however, need not be one in possession; it is sufficient if it is limited by way of remainder. Simes, op. cit. supra note $2, \S$ II9.

${ }^{23}$ The intent of the donor is given effect in those generally recognized situations not falling within the rule-for example, where the estate in the ancestor has been created by a separate conveyance, or the estate in the ancestor is equitable and that in the heirs legal. Theobald, Law of Wills $365-66$ (gth ed. I939).

14 I Hargrave Law Tracts 487 ( 1787 ). 
as purchasers; namely, where no estate of freehold is devised to the ancestor or where the attempted estate of freehold fails because the ancestor predeceases the testator. ${ }^{\mathrm{IS}}$ The same question may be formulated in yet another manner. If the rule still retains enough of its possible historical explanation, then it may have no application unless the ancestor takes an estate of freehold. But if the rule has now become purely formal, then a limitation to "A for life and then to his heirs," assuming the other elements necessary to the application of the rule are present, is exactly equivalent to a limitation to "A and his heirs."

This question came before the English courts in Ambrose v. Hodgson. ${ }^{\mathrm{I7}}$ This case, like the Coulson case, involved a devise to A for life, remainder to trustees to support contingent remainders for the life of $A$, remainder to the heirs of $A$ 's body, with a remainder over on default of such issue. The material difference between the two cases was that in the Ambrose case A predeceased the testator, leaving a daughter surviving her. One of the questions before the court involved the determination of what interest, if any, the daughter could take under the will. In a decision couched in substantially the language used in the Coulson case, the court construed the remainder to the heirs of A's body to be a limitation upon A's estate, which, like A's life estate, lapsed because of A's predeceasing the testator. Clearly, the death of $\mathrm{A}$ and the consequent absence of any life estate in her at the time the testator died, would have provided the court with an adequate basis for distinguishing the Coulson case along the lines indicated by Blackstone. The court apparently deemed A's death irrelevant and concentrated instead on determining whether there was any language present in the instrument which could be construed to describe adequately the daughter as a purchaser. ${ }^{18}$ The Ambrose case was examined somewhat more critically by Preston, ${ }^{39}$ who supported the decision by observing that the effect of the rule in Shelley's Case is to read the remainder given to the heirs as a limitation to the ancestor. Then, if the limitation of the life estate to the an-

85 Ibid., at 504-505. Perhaps a more limited meaning should be attached to this statement of Blackstone. At that time, there was some earlier authority to the contrary. Goodright v. Wright, I P. Wms. 397 (I7I7); cf. Fuller v. Fuller, Cro. Eliz. 442 (r594). It is possible that Blackstone was only referring to situations obviously not within the rule, as where the life estate was not given to the ancestor in the same instrument as the remainder to the heirs, or where the life estate was given to someone other than the ancestor. See the arguments of counsel in Doe, Lessee of the Earl Lindsey v. Colyear, II East 548, 557-58 (I809); see also Fearne, op. cit. supra note Io, at I87, I93-94; Van Grutten v. Foxwell, [r897] A. C. 658, 675 .

${ }^{16}$ See Hargreaves, Shelley's Ghost, 54 Law Q. Rev. 70, $7^{6-77}$ ( 1938 ).

${ }^{27} 3$ Bro. P.C. 416 (278I).

${ }^{18}$ In a later case in which the ancestor predeceased the testator, the court regarded the rule as applying in the absence of any particular intention expressed on the face of the will varying the legal effect of the technical language used. Doe, Lessee of the Earl of Lindsey v. Colyear, II East 548 (I809).

x9 I Preston, Estates 292, 328 (1820). 
cestor fails, the limitation to the heirs would also fail. ${ }^{20}$ From the Ambrose case, it would appear that the English courts finally adopted the formal view of the rule, i.e., giving a certain legal effect to certain language.

The Illinois Supreme Court was confronted with an analogous problem in Lydick v. Tate, ${ }^{2 \mathrm{I}}$ in which case $\mathrm{T}$ devised certain property to A for life or until she remarried, and upon her death or remarriage to her heirs. At the time of the execution of the will, A was unmarried, but she later married during the life of the testator and was married at the time of his death. Since the rule in Shelley's Case operates only on the remainder, the merger of the remainder and the life estate is not prevented because the life estate is subject to some special limitation. ${ }^{22}$ Hence, while the conditions determining the life estates in the Ambrose and the Lydick cases differ, the two cases present substantially the same problem: i.e., whether the rule in Shelley's Case applies if, at the time the instrument becomes operative, the attempted life estate to the ancestor has failed. However, the Illinois court selected a rationale in applying the rule different from that developed in the English courts; it said that the fact that the will manifested an intention to create a life estate in the ancestor was adequate to bring the devise within the rule. Since, in the absence of an intermediate estate the life estate is destroyed simultaneously with its vesting by merging in a greater estate, the court stated that there was no need for a life estate to vest first in A. ${ }^{23}$ In this rationale, however, the court has apparently overlooked the fact that unless the rule in Shelley's Case gives to the language in the will some effect at the time it is executed, there clearly is no life estate at the time the instrument becomes operative. Therefore, following the reasoning of the court, it is difficult to understand how, in the absence of an actual life estate in A, a merger of a life estate with a remainder to A's heirs can possibly occur so as to create a fee. ${ }^{24}$

While the reasoning in the Lydick case may be subject to question, yet the result can be justified if the English interpretation of the rule in Shelley's Case constitutes a valid precedent. ${ }^{25}$ American courts who have found themselves

20 Jarman also regarded the doctrine of the Ambrose case as settled law prior to the enactment of the English anti-lapse statute, I Vict., c. 26, \$ 32 (I837). 3 Jarman, Wills 1840 ( 7 th ed. I930).

${ }^{2 x} 380$ Ill. 616, 44 N.E. (2d) 583 (1942).

${ }_{22}$ Simes, op. cit. supra note $2, \S 130$.

${ }_{23}$ Lydick v. Tate, 380 Ill. 616, 628-29, 44 N.E. (2d) 583, 590-9r (I942).

34 Dowling, Rationale of the Rule in Shelley's Case in Indiana, r3 Ind. L.J. 466, 477 (I938); cf. Kales, Future Interests in Illinois $\$ 44^{\circ}$ ( $x_{920}$ ).

${ }_{25}$ The later developments of the English common law are not usually regarded as binding on the American courts. One court, for example, has suggested that the rule in Shelley's Case is not necessarily applicable to wills since Perrin v. Blake was decided after the common law was brought to this country. Westcott v. Meeker, I44 Iowa 3II, 3I8, I22 N.W. 964, 967 (rgog). For a history of the development of the rule in Shelley's Case in Illinois, see Aetna Life Ins. 
committed to the rule either by prior decision or because the rule was deemed a part of the common law, have generally sought to limit the scope of the rule. ${ }^{26}$ The reasons which are adduced for the qualification of the rule are not always beyond reproach. On one occasion, the Illinois Supreme Court held the rule inapplicable where the remainder to the heirs was subject to a condition precedent. ${ }^{27}$ This decision, which would restrict the operation of the rule, stands in marked contrast to the broad interpretation given the rule in the Lydick case. The result is the development of a rule which is not always the same as its English counterpart and which renders less persuasive English precedents several centuries old. ${ }^{28}$

There is a scarcity of American authority dealing with problems analogous to the one in the Lydick case. ${ }^{29}$ What authority there is usually emphasizes the desirability of restricting the application of the rule in Shelley's Case. One case holds that where the life estate alone is subject to a condition precedent, the rule does not apply until such a time as the condition is determined..$^{\circ}$ By way of dictum, the court in that case indicated that, should the life estate fail, the heirs would then take as purchasers. There is also some authority holding that whether the language of an instrument is within the rule or not should be determined at the time the instrument becomes effective. ${ }^{3 x}$

The rule in Shelley's Case as stated by the Restatement of Property is also qualified by the requirement that the instrument be effective at the time the

Co. v. Hoppin, $2{ }_{4}$ Fed. 928 (C.C.A. $7^{\text {th }}$ rgr4 $_{4}$ ). There is one Tllinois precedent, however, which tends to support the decision in the Lydick case. In Belleville Savings Bank v. Aneshaensel, 298 Ill. 292, I3I N.E. 682 (I92I), the rule was applied to a devise although the ancestor had predeceased the testator. The case is not very persuasive since the application of the rule to the devise was assumed by the court and conceded by counsel. Tbid., at 301 and 686 . The court in the Lydick case, however, cited the Belleville case only as to a collateral point and did not discuss its possible application to the principal issue.

${ }^{26}$ Compare, for example, the Coulson case with Bucklin v. Creighton, I8 R.I. 325,27 Atl. 221 (1893).

${ }^{27}$ Gehlbach v. Briegel, 359 Ill. 3 I6, I94 N.E. 59r (I934); see notes in 3 Univ. Chi. L. Rev. I3I (I935), 45 Yale I. J. $35^{2}$ (I935) criticizing the decision. In a recent decision, the Illinois court has indicated that the holding of the Gehlbach case is not to be followed. Richardson v. Roney, 47 N.E. (2d) 714, 716-I7 (IIl. I943).

${ }^{28}$ For example, since primogeniture never became a part of American law, the word "heirs" could never mean in the United States an indefinite succession of generations such as theoretically the English rule required. Leach, op. cit. supra note 4, at I2I; Kales, op. cit. supra note $24, \$ \$ 423-28$.

29 Except for the case of Belleville Savings Bank v. Aneshaensel, 298 III. 292, x3I N.E. 682 (I92I), note 25 supra, no other cases on this point were found by the American Law Institute. Rest., Property 158-59 (Tent. Draft No. 6 1935).

${ }^{30}$ Starnes v. Hill, II2 N.C. I, I6 S.E. IorI (I893).

${ }^{3 x}$ Simes, op. cit. supra note $2, \S$ I34. This is the time that is selected for determining the application of other technical rules of property, such as the rule against remoteness. Gray, The Rule against Perpetuities \& 23I (R. Gray ed. r942). 
rule is applied. ${ }^{32}$ Furthermore, the Restatement, in a Comment, specifically regards the rule as inapplicable unless there is a life estate created in the ancestor. ${ }^{33}$ Hence, the Restatement treats a devise to A for life, with remainder to his heirs, as not within the operation of the rule if A predeceases the testator. Certainly, this position of the Restatement is in accord with any view of the rule which emphasizes that the ancestor should take an estate of freehold. While the development of the rule in Shelley's Case in England lends some support to the decision in the Lydick case, in the absence of more persuasive precedent, the position taken by the Restatement appears to be more desirable as limiting the scope of an archaic and obsolete rule of property.

\section{UNREALIZED APPRECIATION-COMMENTS ON MODERN DIVIDEND STATUTES}

Is surplus which represents unrealized appreciation of fixed assets legally available for cash dividends? ${ }^{x}$ In Randall $v$. Bailey such dividends were recently held authorized under the provisions of the New York Stock Corporation Law. The corporation had written up the value of its waterfront terminal property to over five times its original cost. From I929 through I932 a generous dividend policy was pursued even though the distributions considerably exceeded net income for the period. If the company had not listed its fixed assets at the appreciated value, the total of its liabilities and capital stock would have considerably exceeded its total assets throughout the period in question. On April I, I933, only eleven months after the last dividend distribution, the company went into receivership, culminating in reorganization.

Section 58 of the New York Stock Corporation Law provides: "No stock corporation shall declare or pay any dividend which shall impair its capital, nor .... declare or pay any dividend .... unless the value of its assets remaining after the payment of such dividend .... shall be at least equal to the aggregate amount of its debts and liabilities, including capital." 2 The trustee appointed in the reorganization proceeding sought to recover from directors of

${ }^{32} 3$ Rest., Property $\S 312$ (1940).

33 Ibid., at Comment c. Among the earlier writers, Kent is in accord with the Restatement. 4 Kent, Commentaries on American Law 259-60 ( $\mathrm{r}_{4}$ th ed. I896). It seems likely that Kent was relying on the authority of Blackstone, note 15 supra. As to other writers, who in other connections seem to imply the necessity for the ancestor to take a life estate, see I Hayes, Conveyancing $54^{2-46}$ ( 5 th ed. 1840 ); - Kales op. cit. supra note $24, \$ 440$. Actually, whether or not the position of the Restatement is adopted, where the ancestor predeceases the testator, many American lapse statutes would limit the number of situations in which the problem might arise.

^ 288 N.Y. 280, 43 N.E. (2d) 43 (I942).

$=$ N.Y. Stock Corp. Laws (McKinney, 1940) $\S 58$. 